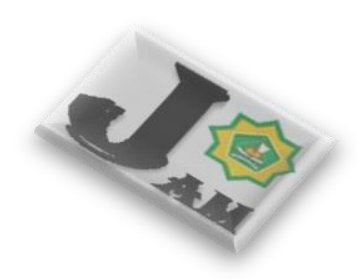

Al-Muqayyad

ISSN (print): 2715-3177 | ISSN (online): 2614-8102

Program Studi Ekonomi Syariah, STAI Auliaurrasyidin Tembilahan Journal Homepage: https://ejournal.stai-tbh.ac.id/index.php/al-muqayyad

\title{
Kartu Kredit Syariah: Perspektif Hukum Islam
}

*Imam Wahyu Hardiansyah ${ }^{1, \text { a }}$

1) IAIN Ponorogo, Jawa Timur, Indonesia

Email: imamhard7@gmail.com

\begin{tabular}{|c|c|}
\hline $\begin{array}{l}\text { DOI: } \\
\text { https://doi.org/10.469 } \\
\underline{\text { 63/jam.v4i1.213 }}\end{array}$ & $\begin{array}{l}\text { Cara Mensitasi Artikel ini: } \\
\text { Hardiansyah. I. W. (2021). Kartu kredit syariah: Perspektif hukum Islam. AL-Muqayyad, } \\
\text { 4(1), 45-52. https://doi.org/10.46963/jam.v4i1.213 }\end{array}$ \\
\hline \multirow{3}{*}{$\begin{array}{l}\text { Keywords: } \\
\text { Syariah Charge } \\
\text { Card, Islam, } \\
\text { Perspective } \\
\text { Kata Kunci: } \\
\text { Kartu Kredit Syariah, } \\
\text { Islam, Perspektif }\end{array}$} & ABSTRACT \\
\hline & $\begin{array}{l}\text { Credit cards are one of the most common methods of payment in modern society. } \\
\text { Credit cards are used to replace payments for the purchase of products and } \\
\text { services. In cities, the Public usually uses this credit card to shop at retail stores } \\
\text { and malls. The rapid development of the use of credit cards currently because } \\
\text { people feel the cards as a means of payment and taking cash considering the } \\
\text { practicality, comfort, and security. The basic law of sharia charge cards, } \\
\text { however, has been explained in the Quran, Hadith, and also Ijma'. }\end{array}$ \\
\hline & ABSTRAK \\
\hline $\begin{array}{l}\text { Informasi Artikel: } \\
\text { Diterima: } \\
11 / 11 / 2020 \\
\text { Direvisi: } \\
\text { Diterbitkan } \\
30 / 06 / 2021\end{array}$ & $\begin{array}{l}\text { Kartu kredit merupakan salah satu alat pembayaran yang kini banyak ditemukan } \\
\text { di masyarakat modern. Kartu kredit digunakan untuk menggantikan } \\
\text { pembayaran suatu pembelian produk dan jasa oleh masyarakat. Di kota besar } \\
\text { tentunya tidak asing lagi untuk berbelanja di toko-toko ritel hingga mall dengan } \\
\text { menggunakan kartu kredit. Perkembangan penggunaan kartu kredit yang begitu } \\
\text { pesat saat ini disebabkan karena masyarakat merasakan semakin pentingnya } \\
\text { penggunaan kartu kredit sebagai alat pembayaran dan mengambil uang tunai } \\
\text { mengingat kepraktisan, rasa nyaman dan aman yang ditimbulkan. Oleh } \\
\text { karenanya, hukum dasar kartu kredit syariah telah dijelaskan dalam Al-Quran, } \\
\text { Hadits, dan juga Ijma'. }\end{array}$ \\
\hline
\end{tabular}

\section{PENDAHULUAN}

Kartu kredit merupakan kartu yang diterbitkan oleh pihak bank yang dapat digunakan untuk membeli sesuatu secara hutang. Kartu kredit digunakan untuk menggantikan pembayaran suatu pembelian produk dan jasa oleh masyarakat. Di kota besar tentunya tidak asing lagi untuk berbelanja di toko-toko ritel hingga mall dengan menggunakan kartu kredit. Kartu kredit memberikan banyak kemudahan untuk pengguna bahkan memberikan reward hingga diskon untuk setiap pembelanjaan yang menggunakan kartu kredit tertentu. Selain itu, kartu kredit tergolong mudah untuk didapatkan dan digunakan. Dengan persyaratan umum seperti slip gaji, KTP dan NPWP maka kartu kredit siap untuk dimiliki. Selain itu, juga kartu kredit juga memiliki fasilitas kartu tambahan yang dapat diatasnamakan orang lain sehingga anak-anak pun dapat 
Imam Wahyu Hardiansyah

memperoleh kartu kredit yang tentunya kartu kredit utamanya adalah milik orang tua maupun orang yang mendaftarkan diri untuk memperoleh kartu kredit.

Perkembangan penggunaan kartu kredit yang begitu pesat saat ini disebabkan karena masyarakat merasakan semakin pentingnya penggunaan kartu kredit sebagai alat pembayaran dan mengambil uang tunai mengingat kepraktisan, rasa nyaman dan aman yang ditimbulkan.

\section{METODE}

Metode yang digunakan dalam penulisan artikel ini adalah kajian pustaka yaitu mengumpulkan buku-buku atau sumber-sumber lain yang berhubungan dengan Kartu Kredit Syariah. Harapan penulis adalah artikel ini dapat menambah pengetahuan dan wawasan terkait Kartu Kredit Syariah.

\section{HASIL DAN PEMBAHASAN}

Pengertian kartu kredit Charge Card dinamakan juga dengan Bithaah Al-Wafa' Al Mu'ajjal atau dengan Bithaqah Al-Khasam Al-Syahri. Kartu ini merupakan kartu yang diterbitkan oleh issuer bank (pihak penerbit kartu) kepada Cald Holder (pemakai kartu) untuk memperoleh kredit pada masa tertentu sesuai dengan klasifikasinya apakah silver atau gold dan semuanya harus dilunasi pada masa yang telah disepakati sebelumnya. Issuer Bank akan menempatkan denda finansial ketika terjadi keterlambatan pembiayaan. (Abdul Wahab Ibrahim, 2006: 52).

Menurut Leksikon Bank Indonesia, syariah charge card adalah fasilitas kartu talangan yang dipergunakan oleh pemegang kartu (Hamil Al-Bithaqah) sebagai alat bayar atau pengambilan uang tunai pada tempat-tempat tertentu yang harus dibayar lunas kepada pihak yang memberikan talangan (Musdir Al-Bithaqah) pada waktu yang telah ditentukan. (Ahmad Ifham, 2015: 290).

Syariah Charge Card atau Kartu kredit "Bithaqah I’timan" biasa disebut "Bithaqah Isti'man" adalah memberikan hak kepada orang lain atas hartanya dengan ikatan kepercayaan, sehingga orang tersebut tidak bertanggung jawab kecuali ketika melakukan keteledoran atau pelanggaran. Menurut Fatwa Dewan Syariah Nasional No.42/DSNMUI/V/2004, Syariah Charge Card adalah fasilitas kartu talangan yang dipergunakan oleh pemegang kartu (Hamil Al-Bithaqah) sebagai alat bayar atau pengambilan uang tunai pada tempat-tempat tertentu yang harus dibayar lunas kepada pihak-pihak yang

\section{Al-Muqayyad}

Vol. 4 No. 1 (2021) 
Kartu Kredit Syariah: Perspektif Hukum Islam

memberikan talangan (Mushdir Al-Bithaqah) pada waktu yang telah ditetapkan dan fatwa tersebut kemudian diperbaharui dengan Fatwa Dewan Syariah Nasional No.54/DSNMUI/X/2006.19.

Di Indonesia, pemain kartu kredit syariah juga masih sedikit. Baru BNI Syariah, Danamon Syariah dan CIMB Niaga Syariah yang menggarap segmen kartu utang ini. Yang menarik, Charge Card ala bank syariah ini ternyata biayanya lebih murah dari pada kartu kredit konvensional.

\section{Landasan Hukum Kartu Kredit}

Al-Qur'an

Salah satu dasar diperbolehkannya kartu kredit syariah adalah firman Allah SWT adalah mengenai akad-akad muamalah yang tercantum dalam surat Al-Maidah ayat 1, yang artinya "Hai orang-orang yang beriman, penuhilah akad-akad itu. Dihalalkan bagimu binatang ternak kecuali yang akan dibacakan kepadamu. (Yang demikian itu) dengan tidak menghalalkan berburu ketika kamu sedang mengerjakan haji. Sesungguhnya Allah menetapkan hukum-hukum menurut yang dikehendaki-Nya.”

Mengenai anjuran untuk saling tolong-menolong, sebagaimana tercantum dalam surat al-Maidah ayat 2, yang artinya "Hai orang-orang beriman, janganlah kamu melanggar syiar-syiar Allah, dan jangan melanggar kehormatan bulan-bulan haram, jangan (mengganggu) binatang-binatang had-ya dan binatang-binatang Qalaa-Id, dan jangan pula mengganggu orang-orang yang mengunjungi Baitullah yang sedang mencari karunia dan keridhaan dari Tuhan-Nya. Dan apabila kamu telah menyelesaikan ibadah haji maka bolehlah berburu, dan janganlah sekali-kali kebencianmu kepada sesuatu kaum karena mereka menghalang-halangi kamu dari Masjidil Haram yang mendorongmu berbuat aniaya (kepada mereka). Dan tolong-menolonglah kamu dalam mengerjakan kebajikan dan takwa. Dan jangan tolong-menolong dalam berbuat dosa dan pelanggaran, dan bertakwalah kamu kepada Allah, sesungguhnya Allah amat berat siksa-Nya. (Indah Nuhyatia, 2015: 33).

\section{Hadits}

Merujuk kepada hadist Nabi Muhammad saw. yang relevan dengan kartu kredit syariah adalah: 
Imam Wahyu Hardiansyah

1. "Perjanjian boleh dilakukan diantara kaum muslimin kecuali perjanjian mengharamkan yang halal atau menghalalkan yang haram. Dan kaum muslimin terikat dengan syarat-syarat mereka kecuali syarat yang mengharamkan yang halal atau menghalalkan yang haram”. (HR. Tirmidzi)

2. "Tidak boleh membahayakan (merugikan) diri sendiri maupun orang lain." (HR Ibnu Majah dan al-Daraquthni)

3. "Telah dihadapkan kepada Rasulullah saw. jenazah seorang laki-laki untuk dishalatkan. Rasulullah bertanya: “Apakah ia mempunyai utang?” Sahabat menjawab, Tidak. Maka beliau menshalatkannya. Kemudian dihadapkan lagi jenazah yang lain. Rasulullah pun bertanya, “Apakah ia mempunyai hutang?” mereka menjawab, ya. Rasulullah berkata, "shalatkanlah temanmu itu (beliau sendiri tidak mau menshalatkannya). Lalu Abu Qatadah berkata "saya menjamin hutangnya ya Rasulullah” Maka Rasulullah pun mensholatkan jenazah tersebut.” (HR. Bukhari)

4. “Zaim (penjamin) adalah gharim (orang yang menanggung)." (HR. Abu Daud, Tirmidzi dan Ibnu Hiibban)

5. "Kami pernah menyewakan tanah dengan (bayaran) hasil pertaniannya. Maka Rasulullah melarang kami melakukan hal tersebut dan memerintahkan agar kami menyewakannya dengan emas atau perak.” (HR Abu Daud)

6. "Orang-orang yang melepaskan seorang muslim dari kesulitannya di dunia, Allah akan melepaskan kesulitannya di hari kiamat, dan Allah senantiasa menolong hambaNya selama ia (suka) menolong saudaranya". (HR. Muslim)

7. "Orang yang terbaik diantara kamu adalah orang yang paling baik dalam pembayaran utangnya." (HR. Bukhari). (Indah Nuhyatia, 2015: 35)

Hadist-hadist tersebut dapat dijadikan landasan akad-akad dalam kartu kredit syariah yang berkenaan dengan konsep halal dan haram, jaminan utang, anjuran untuk tidak menunda-nunda hutang dan membayarnya dengan tepat waktu, memberikan upah bagi yang melakukan pekerjaan dan melakukan tolong menolong. Konsep dari hadist tersebut digunakan dalam aplikasi akad dalam kartu kredit syariah.

Ijma'

Para Ulama membolehkan kartu kredit syariah dalam sistem dan praktik Kafalah dalam muamalah berdasarkan dalil Al-Quran, sunnah dan Ijma'. Allah berfirman: “dan

\section{Al-Muqayyad}

Vol. 4 No. 1 (2021) 
siapa yang dapat mengembalikan akan memperoleh bahan makanan (seberat) beban unta, dan aku menjamin terhadapnya." (Q.S Yusuf:72). Sedangkan Ibnu Abbas mengatakan bahwa yang dimaksud dengan kata "zaim" dalam ayat tersebut adalah "kafil". (Indah Nuhyatia, $2015: 36)$.

Dalam Kitab Mughni Al-Muhtaj, jilid II:201-202: “(Hal yang dijamin) yaitu hutang (disyariatkan harus berupa hak yang telah terjadi) pada saat akad. Oleh karena itu, tidak sah menjamin hutang yang belum menjadi kewajiban. (Qaul Qadim) Imam Syafi'i mengatakan sah penjaminan terhadap hutang yang kan menjadi kewajibannya, seperti harga barang yang akan dijual atau sesuatu yang akan dihutangkan. Hal itu karena hajat, kebutuhan orang terkadang mendorong adanya penjaminan tersebut. Dari penjelasan di atas menjadi sandaran MUI dalam penggunaan akad Kafalah dalam transaksi Syariah Charge Card, di dalam fatwa ini, juga terdapat penggunaan kaidah Fiqh di antaranya:

1. Pada dasarnya semua bentuk muamalah boleh dilakukan kecuali ada dalil yang melarangnya

2. Keperluan dapat menduduki posisi darurat

Apa pun batasan syariah yang lain yang tertuang dalam Fatwa MUI mengenai Syariah Charge Card adalah tidak boleh menimbulkan riba dan melakukan transaksi atas barang-barang yang haram dan maksiat. Ketentuan ini didasarkan pada dalil QS. AlBaqarah: 275 yang artinya “orang yang makan (mengambil) riba tidak dapat berdiri melainkan seperti berdirinya orang-orang yang kemasukan syetan lantaran (tekanan) penyakit gila. Keadaan mereka yang demikian itu adalah disebabkan mereka berkata (berpendapat), sesungguhnya jual-beli itu sama dengan riba. Padahal Allah telah menghalalkan jual beli dan mengharamkan riba. Orang-orang telah sampai kepadanya larangan dari Tuhannya, lalu terus berhenti (dari mengambil riba), maka baginya apa yang telah diambilnya dahulu (sebelum datang larangan) dan urusannya (terserah) kepada Allah. Orang-orang yang menghalangi (mengambil riba). Maka orang itu adalah penghuni-penghuni neraka, mereka kekal didalamnya.

\section{Akad dalam Mekanisme Transaksi Kartu Kredit}

Akad yang digunakan dalam penggunaan Syariah card adalah kafalah, qard dan ijarah. Adapun penjelasannya sebagai berikut: 
Imam Wahyu Hardiansyah

1. Kafalah

Akad Kafalah atau disebut saling menanggung. Dalam hal ini penerbit Kartu adalah penjamin (Kafil) bagi pemegang kartu terhadap merchant atas semua kewajiban bayar (Dayn) yang timbul dari transaksi antara pemegang kartu dengan merchant, atau penarikan tunai selain bank atau ATM Bank penerbit kartu. Atas pemberian Kafalah, penerbit kartu dapat menerima fee (Ujrah Kafalah).

2. Qard

Akad Qard atau pinjaman, qardul hasan yaitu pinjaman yang baik. Disebut pinjaman yang baik karena pinjaman tersebut tidak diberikan bunga atau imbalan. Bank Syariah ketika memberikan fasilitas pinjaman dalam kartu pembiayaan berlaku sebagai pemberi pinjaman.

Dalam hal ini penerbit kartu adalah pemberi pinjaman (Muqridh) kepada pemegang kartu (Muqtaridh) melalui penarikan tunai dari Bank atau ATM bank penerbit kartu.

3. Ijarah

Akad ijarah atau disebut juga dengan sewa, dengan menggunakan akad ini, nasabah dikenakan charge sewa penggunaan jasa kartu pembiayaan syariah atau sering disebut juga dengan Wakalah Bil Ujrah.

Dalam hal ini penerbit kartu adalah penyedia jasa sistem pembayaran dan pelayanan terhadap pemegang kartu. Atas ijarah ini, pemegang kartu dikenakan membership fee. Jadi dalam akad ini tampak bahwa ada dua akad yang memberikan peluang untuk mendapatkan keuntungan bagi bank, yaitu kafalah dan ijarah. Sedangkan Qard, bank tidak mengambil keuntungan.

\section{Pembiayaan Syariah Melalui Kartu Kredit}

Produk kartu pembiayaan didukung oleh Fatwa DSN MUI tahun 2006 dan Bank Indonesia tahun 2007. Menurut DSN MUI, kartu pembiayaan syariah adalah kartu yang berfungsi sebagai kartu kredit antara pihak berdasarkan prinsip syariah. Pihak yang dimaksud adalah penerbit kartu atau bank, pemegang kartu atau nasabah serta penerima kartu. (Hafidz Abdurahman, 2011: 18).

Melihat bahwa kartu kredit termasuk transaksi riba, yang status akadnya batil dan diharamkan dalam Islam, maka bank syariah mengeluarkan produk kartu kredit syariah. Adapun akad yang digunakan adalah akad kafalah, qardh dan ijarah.

\section{Al-Muqayyad}

Vol. 4 No. 1 (2021) 
Kartu Kredit Syariah: Perspektif Hukum Islam

Kartu pembiayaan syariah memiliki keistimewaan lebih bila dibandingkan dengan kartu kredit konvensional, seperti penggunaannya untuk sektor produktif, bukan konsumtif. Nasabah pemegang kartu pembiayaan syariah juga dapat membayar zakat, infak dan shadaqah secara otomatis (auto debet) jika nasabah inginkan. Kartu pembiayaan syariah memiliki batasan-batasan yaitu, antara lain sebagai berikut.

1. Tidak menimbulkan riba

2. Tidak digunakan untuk transaksi yang tidak sesuai dengan syariah

3. Tidak mendorong pengeluaran yang berlebihan dengan cara menetapkan pagu maksimal pembelanjaan

4. Pemegang kartu utama harus memiliki kemampuan finansial untuk melunasi pada waktunya

5. Tidak memberikan fasilitas yang bertentangan dengan syariah.

Penerbitan kartu kredit syariah di Indonesia seperti kartu yang diterbitkan oleh

Bank Danamon menggandeng Master Card menerbitkan Dirham Card, BII memiliki produk kartu kredit syariah yaitu tipe BII syariah Card Gold dan Platinum. Sebagai lembaga bisnis penerbit kartu boleh mengambil fee dengan ketentuan, sebagai berikut:

1. Iuran keanggotaan (membership fee), penerbit kartu berhak menerima iuran keanggotaan, termasuk perpanjangan masa keanggotaan dari pemegang kartu sebagai imbalan (ujrah) atas izin penggunaan fasilitas kartu

2. Merchant Fee, penerbit kartu boleh menerima fee yang diambil dari harga objek pemasaran (taswiq) dan penagihan (tahsil al-dayn)

3. Fee penarikan uang tunai, penerbit kartu boleh menerima penarikan uang tunai (rusum sahb al-nuqud) sebagai fee atas pelayanan dan penggunaan fasilitas yang besarnya tidak dikaitkan dengan penerbitan.

4. Fee kafalah, penerbit kartu boleh menerima fee dari pemegang kartu tas pemberian kafalah

5. Semua bentuk fee harus ditetapkan pada saat akad aplikasi kartu secara jelas dan tetap, kecuali untuk merchant fee. (Nining winingsih, 2016: 8). 
Imam Wahyu Hardiansyah

\section{SIMPULAN}

Syariah charge card adalah fasilitas kartu talangan yang dipergunakan oleh pemegang kartu (Hamil Al-Bithaqah) sebagai alat bayar atau pengambilan uang tunai pada tempat-tempat tertentu yang harus dibayar lunas kepada pihak yang memberikan talangan (Musdir Al-Bithaqah) pada waktu yang telah ditentukan. Sedangkan Syariah Charge Card atau Kartu kredit "Bithaqah I'timan" biasa disebut "Bithaqah Isti'man" adalah memberikan hak kepada orang lain atas hartanya dengan ikatan kepercayaan, sehingga orang tersebut tidak bertanggung jawab kecuali ketika melakukan keteledoran atau pelanggaran. Hukum landasan diperbolehkannya syariah charge card telah dijelaskan dalam Al-Quran, sunnah dan juga ijma'.

Akad yang digunakan dalam syariah charge card terdapat tiga, yaitu Akad Kafalah (saling menanggung), akad Qard (pinjaman) dan akad Ijarah (sewa). Dalam produk kartu pembiayaan didukung oleh Fatwa DSN MUI tahun 2006 dan Bank Indonesia tahun 2007. Menurut DSN MUI, kartu pembiayaan syariah adalah kartu yang berfungsi sebagai kartu kredit antara pihak berdasarkan prinsip syariah. Pihak yang dimaksud adalah penerbit kartu atau bank, pemegang kartu atau nasabah serta penerima kartu.

\section{REFERENSI}

Abdurrahman, H. (2011). Hukum Islam Seputar Kartu Kredit. Bogor: Al-Azhar press.

Ibrahim, A. W. (2006). Banking card syariah: Kartu kredit dan debit dalam perspektif fiqh. Jakarta: PT Raja Grafindo Persada.

Ifham, A. (2015). Ini Lho Bank Syariah (Memahami Bank Syariah dengan Mudah). Jakarta: Gramedia

Nuhyatia, I. (2015). Kajian fiqh dan perkembangan kartu kredit syariah (Syariah Card) di Indonesia. Economic: Jurnal Ekonomi dan Hukum Islam, 5(1). 23-50.

Wahyuningsih, N. (2016). Kartu Kredit (Suatu Tinjauan Syariat Islam). Al-Amwal: Jurnal Ekonomi dan Perbankan Syari'ah, 5(2).

\section{Al-Muqayyad}

Vol. 4 No. 1 (2021) 